\title{
Antigenic characterization of Brazilian bovine viral diarrhea virus isolates by monoclonal antibodies and cross-neutralization
}

\section{S.A. Botton, A.M. da-Silva, \\ M.C.S. Brum, R. W eiblen and E.F. Flores}

Departamento de Medicina Veterinária Preventiva, M icrobiologia e Parasitologia, Universidade Federal de Santa Maria, Santa Maria, RS, Brasil

\section{Correspondence \\ E.F. Flores \\ Departamento de Medicina \\ Veterinária Preventiva, UFSM \\ 97015-900 Santa Maria, RS \\ Brasil \\ Fax: +55-55-220-8257 \\ E-mail: flores@ccr.ufsm.br \\ Research supported by MCT, CNPq, CAPES and FINEP (PRONEX em \\ Virologia Veterinária, No. 215/96) and FAPERGS (No. 96/1471.6). \\ S.A. Botton and A.M. Silva are recipients of CAPES and $\mathrm{CNPq}$ scholarships, respectively. E.F. Flores and R. W eiblen are recipients of $\mathrm{CNPq}$ fellowships (Nos. 352386/96 and 520011/95, respectively).}

Received M arch 20, 1998 Accepted August 13, 1998

\begin{abstract}
Nineteen Brazilian isolates of bovine viral diarrhea virus (BVDV) were characterized antigenically with a panel of 19 monoclonal antibodies (mAbs) (Corapi WV, Donis RO and Dubovi EJ (1990) American Journal of Veterinary Research, 55: 1388-1394). Eight isolates were further characterized by cross-neutralization using sheep monospecific antisera. Analysis of mAb binding to viral antigens by indirect immunofluorescence revealed distinct patterns of reactivity among the native viruses. Local isolates differed from the prototype Singer strain in recognition by up to $14 \mathrm{mAbs}$. Only two mAbs - one to the non-structural protein NS23/p125 and another to the envelope glycoprotein E0/gp 48 - recognized $100 \%$ of the isolates. No isolate was recognized by more than $14 \mathrm{mAbs}$ and twelve viruses reacted with 10 or less mAbs. mAbs to the major envelope glycoprotein E2/gp53 revealed a particularly high degree of antigenic variability in this glycoprotein. Nine isolates (47.3\%) reacted with three or less of 10E2/ gp53 mAbs, and one isolate was not recognized by any of these mAbs. Virus-specific antisera to eight isolates plus three standard BVDV strains raised in lambs had virus-neutralizing titers ranging from 400 to 3200 against the homologous virus. Nonetheless, many antisera showed significantly reduced neutralizing activity when tested against heterologous viruses. Up to 128 -fold differences in cross-neutralization titers were observed for some pairs of viruses. When the coefficient of antigenic similarity (R) was calculated, 49 of 66 comparisons (74.24\%) between viruses resulted in $\mathrm{R}$ values that antigenically distinguish strains. Moreover, one isolate had $\mathrm{R}$ values suggesting that it belongs to a distinct serologic group. The marked antigenic diversity observed among Brazilian BVDV isolates should be considered when planning diagnostic and immunization strategies.
\end{abstract}

Key words

- Bovine viral diarrhea virus

- BVDV

- Monoclonal antibodies

- Cross-neutralization

- Antigenic diversity 


\section{Introduction}

Bovine viral diarrhea virus (BVDV) is an important cattle pathogen which causes significant losses to the livestock industry around the world $(1,2)$. BVDV is currently classified within the Flaviviridae, genus Pestivirus, along with the classical swine fever virus (CSFV) and border disease virus (BDV) of sheep (3). Pestiviruses are small enveloped, positive-sense RNA viruses $(4,5)$ which naturally infect swine and domestic and wild ruminants (6). Pestiviruses display considerable genetic and antigenic diversity within the genus, although all members cross-react serologically to some extent (7).

BVDV infections in cattle are associated with a variety of clinical manifestations including inapparent infections, gastroenteric, respiratory, and hemorrhagic syndromes and the deadly mucosal disease (MD) (8-10). Infection of pregnant cows by the noncytopathic BVDV biotype may result in a variety of outcomes: early or late embryonic death, abortion or mummification, malformations, stillbirth and birth of weak and non-thriving calves (10). Infection of fetuses between 40 and 120 days of gestation often leads to fetal immunotolerance, resulting in the birth of immunotolerant persistently infected (PI) calves $(9,10)$. Most persistently infected animals develop and die of mucosal disease within the first 6 to 24 months of life $(2,9)$. Cytopathic and noncytopathic BVDV biotypes are usually isolated from animals affected by MD (9). Cytopathic BVD viruses originate from their noncytopathic counterpart through mutations, recombinations or rearrangements in the viral RNA genome $(11,12)$.

Serological studies have shown that although BVDV field isolates are antigenically related to each other, antigenic differences can be readily detected among viruses (7,13-15). These antigenic differences have been demonstrated by the use of monoclonal antibodies (mAbs) and by in vitro and in vivo cross-neutralization studies (7,13-16). However, in spite of the antigenic variability, no clear definition of serotypes has been possible to date $(7,16)$. The marked antigenic variability of BVD viruses allows differentiation between strains, but also represents a potential problem for diagnosis and immunization strategies $(7,16)$.

Very little is known about BVDV infection and disease in Brazil. The presence of BVDV infection in the country was first indicated by clinical reports and serological studies conducted in the 60's and 70's (1719). Thereafter, serologic and virologic data have confirmed the widespread distribution of BVDV infection among Brazilian cattle $(20,21)$. To date, approximately 20 BVD isolates have been isolated in Brazil (Botton SA and Flores EF, unpublished results). The present article reports the antigenic characterization of 19 of these isolates. Analysis of reactivity with a panel of mAbs and crossneutralization studies revealed a marked antigenic diversity among these viruses. This antigenic diversity may have important implications for epidemiologic studies and for the diagnosis and control of BVDV infection in Brazil.

\section{Material and Methods}

\section{Virus isolation, viruses and cells}

Nineteen Brazilian BVDV isolates were studied. Eleven viruses were isolated from the blood of bovine fetuses collected at slaughterhouses in the central region of Rio Grande do Sul State, southern Brazil. Two additional BVDV were isolated from serum of a PI calf (Pelotas, RS) and from the spleen of a heifer with gastroenteric disease (Lages, $\mathrm{SC})$. The other 6 viruses were isolated in other laboratories and sent for characterization (Botton SA and Flores EF, unpublished data). For viral isolation, fetal serum was inoculated onto Madin-Darby bovine kidney cells (MDBK, American Type Culture Col- 
lection. Rockville, MD) and submitted to three blind passages at 48 -h intervals. At the end of the third passage, the inoculated cells were submitted to an indirect immunofluorescence assay (IFA) for viral antigens. IFA was performed in acetone-fixed cells, using a pool of anti-BVDV Singer mAbs (22) as the primary antibody, and an FITC-conjugated anti-mouse IgG (Sigma, St. Louis, MO, USA) as the secondary antibody. The slides were counterstained with Evans blue, mounted with PBS:glycerol (1:1) and observed in an epifluorescence microscope. Samples positive for BVDV antigens were identified and the respective viruses were further cultured in MDBK cells.

\section{Reactivity with monoclonal antibodies}

A panel of $19 \mathrm{mAbs}$ to the prototype BVDV Singer strain (22) was used to characterize the Brazilian isolates. The mAbs were provided by Dr. Ruben Donis, Department of Veterinary and Biomedical Sciences, University of Nebraska at Lincoln, Lincoln, NE, USA. The ability of each individual $\mathrm{mAb}$ to recognize and bind to viral antigens was assayed by IFA. Cells infected with each isolate were incubated with individual mAbs as the primary antibody, followed by incubation with the secondary antibody as described above. Either ascites fluid (1:500 in phosphate buffered saline; PBS) or supernatants of hybridoma cultures were used. Mock-infected cells, cells infected with the prototype Singer strain and stained with each individual $\mathrm{mAb}$, and cells infected with each isolate and stained with a pool of $\mathrm{mAbs}$ were used as controls.

\section{Production of virus-monospecific antisera}

Virus-specific antisera against three reference BVDV strains (Singer, NADL and Oregon/C24v) and eight Brazilian isolates were produced in lambs. Eleven BVDVseronegative, 6- to 8-month-old lambs were inoculated intranasally and intramuscularly with approximately $10^{7}$ TCID $_{50}$ (tissue culture median infectious dose) of each virus. The animals were housed individually until the second serum collection. Blood was collected at 15 and 30 days post-inoculation (pi) to obtain serum which was heat inactivated at $56^{\circ} \mathrm{C}$ for $30 \mathrm{~min}$ prior to virus neutralization $(\mathrm{VN})$ assays.

\section{Virus-neutralization assays}

Individual serum samples collected at 15 and 30 days $p i$ were initially titrated against their homologous viruses in a standard VN assay (15). The serum samples obtained at 30 days $p i$ (which had the highest VN titer) were titrated against each heterologous virus and the neutralization end points were determined for each virus-serum combination. $\mathrm{VN}$ assays were performed in polystyrene 96-well plates, using doubling two-fold dilutions of each serum (starting at 1:12.5) against a fixed dose of virus (approximately 100 $\mathrm{TCID}_{50}$ /well) and MDBK cells as indicators. Readings were performed after $96 \mathrm{~h}$ of incubation. Virus growth or neutralization was monitored by microscopic examination of the cytopathic effect for the cytopathic strains (Singer, NADL and Oregon/C24v) or by staining the indicator cells for viral antigens by IFA for the noncytopathic viruses. Whenever a certain serum was titrated with different viruses, the $\mathrm{VN}$ tests were performed at the same time on the same plate, using the same preparation of MDBK cells. The crossneutralization tests yielded 121 values, corresponding to the $\mathrm{VN}$ titer of each virusserum combination. These values are reported as the reciprocal of the highest dilution of serum capable of preventing viral replication (Table 2).

\section{Calculation of antigenic similarity}

The data obtained in the cross-neutralization assays were combined in order to 
calculate the antigenic similarity among the isolates. The neutralization end points for each virus-serum combination were combined as described by Howard et al. (15) to obtain a percent relatedness value for each pair of viruses. The coefficient of antigenic similarity (R) was calculated according to Archetti and Horsfall (23) using the following formula:

$\mathrm{R}=100 \times \sqrt{\frac{\text { titer strain I with antiserum II } x \text { titer strain II with antiserum I }}{\text { titer strain I with antiserum I } x \text { titer strain II with antiserum II }}}$

\section{Results}

\section{BVDV isolates}

BVD viruses were isolated and identified in $0.75 \%(11 / 1396)$ of the blood samples collected from bovine fetuses. One additional virus was isolated from a clinical case

Table 1 - Reactivity of a panel of monoclonal antibodies (mAb) with Brazilian isolates of bovine viral diarrhea virus (BVDV)a.

aAssayed by an indirect immunofluorescence (IFA) assay. bPanel of monoclonal antibodies to the standard BVDV Singer produced and characterized by Corapi et al. (22). 'Reported by Corapi et al. (22) and Carman et al. (24). nd, Not determined.

\begin{tabular}{|c|c|c|c|c|c|}
\hline $\begin{array}{l}\mathrm{mAb} \\
(\mathrm{n}=)\end{array}$ & $\begin{array}{l}\text { Protein } \\
\text { specificity }\end{array}$ & $\begin{array}{l}\mathrm{mAb} \\
\text { identification }\end{array}$ & $\begin{array}{l}\text { mAb } \\
\text { isotype }\end{array}$ & $\begin{array}{l}\text { Reactivity with } \\
\text { Brazilian isolates } \\
\% \text { (positive/total) }\end{array}$ & $\begin{array}{l}\text { Reactivity with } \\
\text { US isolates }(\%)^{c}\end{array}$ \\
\hline 1 & NS23/p125 & 8.12 .7 & $\operatorname{lgG1}$ & $94.7(18 / 19)$ & 100 \\
\hline 2 & & 20.10 .6 & IgG1 & $100(19 / 19)$ & 100 \\
\hline 3 & & 15.14 .15 & $\operatorname{lgGl}$ & 94.7 (18/19) & 100 \\
\hline 4 & E2/gp53 & $12 \mathrm{~g} 4$ & $\operatorname{lgGl}$ & $42.6(8 / 19)$ & 79 \\
\hline 5 & & $19 f 7$ & $\operatorname{lgG} 2 a$ & $57.9(11 / 19)$ & 79.5 \\
\hline 6 & & $27 b 3$ & $\operatorname{lgG} 2 \mathrm{~b}$ & 0 (0/19) & 12.5 \\
\hline 7 & & $20 \mathrm{~g} 7$ & $\operatorname{lgG} 2 a$ & $36.8(7 / 19)$ & 53 \\
\hline 8 & & $6 \mathrm{~d} 11$ & $\operatorname{lgG} 2 a$ & $31.6(6 / 19)$ & 24 \\
\hline 9 & & $10 f 9$ & $\operatorname{lgGl}$ & $15.8(3 / 19)$ & 7.5 \\
\hline 10 & & $18 d 4$ & IgGI & $52.6(10 / 19)$ & 76 \\
\hline 11 & & $4 d 8$ & $\operatorname{lgG} 2 \mathrm{~b}$ & $26.3(5 / 19)$ & 25 \\
\hline 12 & & 7.1 .8 & $\operatorname{lgGl}$ & $94.7(18 / 19)$ & 90 \\
\hline 13 & & $26 c 6$ & $\operatorname{lgGl}$ & $26.3(5 / 19)$ & 35 \\
\hline 14 & E0/gp48 & $15 c 5$ & $\operatorname{lgG} 2 \mathrm{~b}$ & $100(19 / 19)$ & 100 \\
\hline 15 & & $3 d 8$ & $\operatorname{lgGl}$ & $42.6(8 / 19)$ & 57 \\
\hline 16 & Undetermined & $3 c 6$ & $\operatorname{lgG} 3$ & $31.6(6 / 19)$ & 61 \\
\hline 17 & & $6 c 5$ & nd & $42.6(8 / 19)$ & nd \\
\hline 18 & & $32 \mathrm{~b} 3$ & $\operatorname{lgG} 3$ & $21.1(4 / 19)$ & 57.5 \\
\hline 19 & & $2 \mathrm{~d} 5$ & nd & $26.3(5 / 19)$ & nd \\
\hline
\end{tabular}

of gastroenteric disease and another from the serum of an apparently healthy calf from a dairy herd. All these isolates were of the noncytopathic biotype. The origin and preliminary characterization of these and other 6 viruses isolated in other laboratories will be described elsewhere (Botton SA and Flores EF, unpublished data).

\section{Reactivity with monoclonal antibodies}

The protein specificity of the mAbs used in this study and a summary of their reactivity with Brazilian BVDV isolates are presented in Table 1. The spectrum of reactivity of these mAbs with 81 North-American (US) BVDV isolates is also presented $(22,24)$. $\mathrm{mAbs}$ to the non-structural protein NS23/ p125 (and its cleavage product NS3/p80) showed a broad spectrum of reactivity, recognizing 94.7 to $100 \%$ of the isolates both in the US and Brazilian groups of viruses. One $\mathrm{mAb}$ to the envelope glycoprotein E0/gp48 (15c5) also reacted with $100 \%$ of the isolates. $\mathrm{mAbs}$ to the major envelope glycoprotein E2/gp53 showed a high variation in the spectrum of reactivity with native viruses. Except for a mAb that recognized $18(94.7 \%)$ native viruses (and 90\% of the US's), all other nine mAbs reacted with zero to 11 isolates (57.9\%). Most of the E2/gp53 mAbs recognized a higher number of US than Brazilian isolates, although equivalent and lower recognition rates of US viruses were also observed (Table 1). Four mAbs of undetermined protein specificity displayed a variable spectrum of reactivity recognizing from 21.1 to $47.4 \%$ of the native isolates (Table 1). The profile of reactivity of the 19 $\mathrm{mAbs}$ with each Brazilian isolate plus the standard US BVDV strains is presented in Figure 1.

\section{Virus-neutralization}

Virus-specific antisera produced in lambs against three BVDV standard strains and 8 


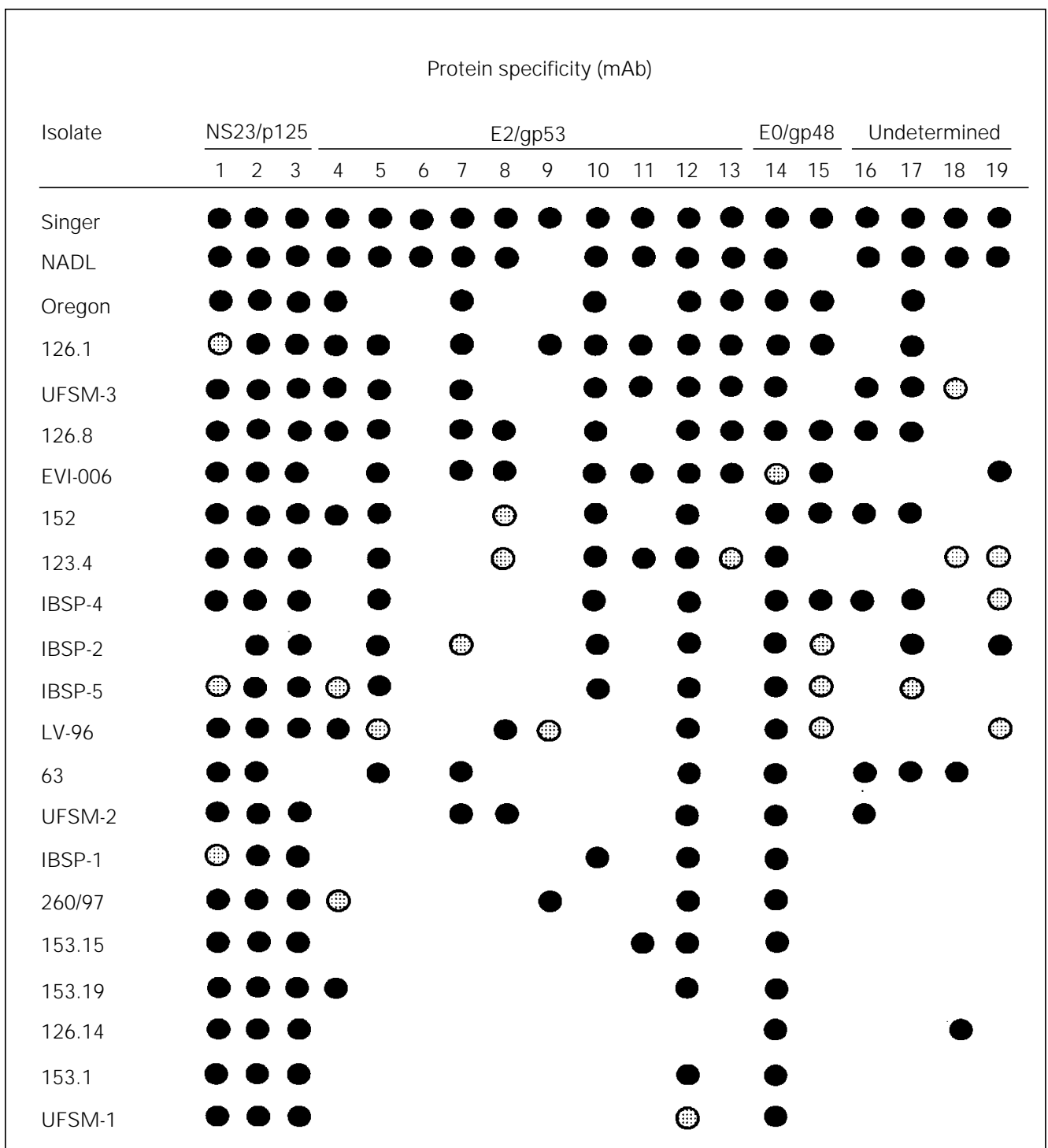

Strong fluorescence

Faint fluorescence native isolates had moderate to high levels of neutralizing antibodies. The VN titers against the homologous virus in sera collected at 30 days $p i$ ranged from 400 to 3200 (Table 2). Testing these sera against heterologous viruses, however, yielded variable and often significantly lower VN titers. Sixtyfour to 128 -fold reductions in titers were observed for some pairs of heterologous serum-virus combinations. Antisera UFSM-1 and 153-1 showed a reduction from 3200 to 25 when tested against isolates 152 and Singer/UFSM-3, respectively. Antiserum 63 also showed a significant reduction of neutralizing activity when tested against most of the viruses examined. Eight-, 16- and 32fold differences in $\mathrm{VN}$ titers were common among the different combinations of heterologous viruses (Table 2).

The VN values for each pair of heterologous viruses were used in order to calculate a coefficient of antigenic similarity (R) between viruses (Table 3 ). An $R$ value of $\leq 25$ represents four-fold differences in titers between homologous and heterologous antisera, indicating significant antigenic differ-
Figure 1 - Reactivity of a panel of monoclonal antibodies (mAb) to the prototype BVDV Singer strain with Brazilian BVDV isolates in an indirect immunofluorescence assay. 
Table 2 - Virus-neutralizing (VN) antibody titers of monospecific sheep antisera against homologous and heterologous BVDVa.

aReciprocal of the highest dilution of serum capable of neutralizing $100 \mathrm{TCID}_{50}$ of the respective virus.

\begin{tabular}{|c|c|c|c|c|c|c|c|c|c|c|c|}
\hline \multirow[t]{2}{*}{ Virus } & \multicolumn{11}{|c|}{ Antiserum to } \\
\hline & Singer & NADL & Oregon & 153.1 & 153.15 & UFSM-3 & 123.4 & 152 & 126.14 & UFSM-1 & 63 \\
\hline Singer & 3200 & 800 & 200 & 400 & 400 & 50 & 200 & 200 & 400 & 50 & 25 \\
\hline NADL & 1600 & 1600 & 100 & 800 & 800 & 100 & 400 & 800 & 800 & 1600 & 12.5 \\
\hline Oregon & 400 & 200 & 400 & 400 & 200 & 100 & 800 & 100 & 100 & 400 & 25 \\
\hline 153.1 & 200 & 200 & 50 & 1600 & 1600 & 12.5 & 400 & 50 & 1600 & 50 & 50 \\
\hline 153.15 & 800 & 400 & 12.5 & 400 & 3200 & $<12.5$ & 400 & 800 & 400 & 50 & 25 \\
\hline UFSM-3 & 800 & 400 & 25 & 400 & 25 & 400 & 400 & 400 & 50 & 400 & 50 \\
\hline 123.4 & 1600 & 50 & 12.5 & 800 & 200 & $<12.5$ & 3200 & 1600 & 800 & 800 & 400 \\
\hline 152 & 400 & 200 & 100 & 800 & 400 & 100 & 1600 & 1600 & 800 & 25 & 50 \\
\hline 126.14 & 100 & 50 & 50 & 400 & 800 & 25 & 800 & 100 & 1600 & 400 & 25 \\
\hline UFSM-1 & 400 & 400 & 25 & 400 & 3200 & 50 & 800 & 200 & 800 & 3200 & 50 \\
\hline 63 & 400 & 100 & 12.5 & 1600 & 1600 & $<12.5$ & 200 & 25 & 400 & 800 & 1600 \\
\hline
\end{tabular}

Table 3 - Coefficient of antigenic similarity (R) for standard strains and Brazilian BVDV isolates, calculated with the VN values for homologous and heterologous pairs of virusesa.

aAccording to Archetti and Horsfall (23). bR values $<5$ are underlined.

\begin{tabular}{|c|c|c|c|c|c|c|c|c|c|c|c|}
\hline \multirow[t]{2}{*}{ Virus } & \multicolumn{11}{|c|}{ Antiserum to } \\
\hline & Singer & NADL & Oregon & 153.1 & 153.15 & UFSM-3 & 123.4 & 152 & 126.14 & UFSM-1 & 63 \\
\hline Singer & 100 & & & & & & & & & & \\
\hline NADL & 50 & 100 & & & & & & & & & \\
\hline Oregon & 25 & 17.68 & 100 & & & & & & & & \\
\hline 153.1 & 12.5 & 25 & 17.68 & 100 & & & & & & & \\
\hline 153.15 & 17.68 & 25 & $4.42 \underline{b}$ & 35.3 & 100 & & & & & & \\
\hline UFSM-3 & 17.68 & 25 & $\overline{12.5}$ & 8.84 & $\underline{15.6}$ & 100 & & & & & \\
\hline 123.4 & 17.68 & 6.25 & 8.84 & 25 & 8.84 & 6.25 & 100 & & & & \\
\hline 152 & 12.5 & 25 & 12.5 & 12.5 & 25 & 25 & 70.71 & 100 & & & \\
\hline 126.14 & 8.84 & 12.5 & 8.84 & 50 & 25 & 4.42 & 35.35 & 17.6 & 100 & & \\
\hline UFSM-1 & $\underline{4.42}$ & 3535 & 8.84 & 6.25 & 12.5 & 12.5 & 25 & $\underline{3.12}$ & 25 & 100 & \\
\hline 63 & $\overline{4.42}$ & 2.21 & $\underline{2.21}$ & 17.6 & 8.84 & $\underline{3.12}$ & 12.25 & 2.21 & 6.25 & 8.84 & 100 \\
\hline
\end{tabular}

ences that are greater than would be expected from the variation in the assay $(15,25)$. $R$ values $\leq 5$ are obtained when $>20$-fold differences in titers occur between homologous and heterologous antisera and have been suggested as the threshold to differentiate serotypes. Forty-nine (74.24\%) of the 66 $R$ values calculated in this study gave values $\leq 25$. These results corroborate those from the monoclonal antibody analysis, which revealed a considerable antigenic variation within this group of viruses. Ten $(15.1 \%)$ of the calculated $\mathrm{R}$ values were $<5$. Five of them $(50 \%)$ involved isolate 63 , and 3 involved isolate UFSM-3. Three other viruses (UFSM-1, 152 and 153.15) yielded two R values below 5 . These results suggest that within an antigenically variable group of viruses isolate 63 is more distantly related and may belong to a distinct serologic group.

\section{Discussion}

Much of the early work on BVDV fo- 
cused on the antigenic similarities rather than on the differences among isolates. The first in vivo cross-protection studies showed that two isolates from different regions of the US were antigenically related to each other, suggesting that immunization with one isolate would protect against heterologous BVDV (25). Likewise, in vitro VN tests demonstrated that BVDV isolated from different clinical syndromes were antigenically related, suggesting that distinct serotypes did not exist $(14,26)$. Thereafter, observations of antigenic relationships were extended to the other Pestiviruses - classical swine fever virus (CSFV) and border disease virus (BDV) $(7,27)$. The concepts of antigenic similarity and of the existence of a single serologic type for BVDV persisted until recently, so that most BVDV vaccines produced up to the 90 's were based on a single BVDV isolate.

It was only with the identification of cytopathic strains that the antigenic diversity of BVDV could be more thoroughly examined. The availability of cytopathic viruses greatly facilitated and improved the in vitro virus-neutralization studies $(7,16)$. Nonetheless, more definitive and precise characterization of the antigenic variability was only possible with the development of BVDVmAbs in the late 1980's $(22,27)$ and more recently, as more BVDV gene sequences became available (28-30).

Production of BVDV-specific mAbs with standard laboratory strains has resulted in two major groups of mAbs: 1) group-specific, which recognize most - if not all - isolates and even other Pestiviruses, and 2) type or strain-specific, which allow differentiation and discrimination among isolates. The first group of mAbs is mainly directed against highly conserved epitopes, mostly in the soluble, non-structural polypeptide NS23/ p125 (7). NS23/p125 is a multifunctional protein whose amino-terminal half (NS3/ p80) is the most conserved polypeptide among Pestiviruses (12). As many epitopes across their sequence are conserved, mAbs to NS3/p80 have a wide application in diagnostic tests by enhancing the accuracy of identification of these viruses in clinical material $(16,22)$.

Type or strain-specific mAbs are mainly directed against the two major envelope glycoproteins (E0/gp48 and E2/gp53). E2/gp53 is thought to be involved in the binding of virions to cellular receptors in such a way that most mAbs directed against it are neutralizing $(12,31,32)$. The E2/gp53 gene contains one of the three hypervariable regions of the viral genome $(12,31)$. Consequently, many E2/gp53 mAbs are directed against epitopes that are differently expressed among isolates, failing to recognize the equivalent epitopes in field isolates. The pattern of reactivity of $10 \mathrm{E} 2 / \mathrm{gp} 53 \mathrm{mAbs}$, however, demonstrated that the variability is not uniformly distributed throughout the protein. mAbs reacting with most isolates, such as $\mathrm{mAb}$ 7.1.8, are probably directed against conserved epitopes which are under strong structural constraints or simply not subjected to immunologic pressure, or both. In contrast, mAbs reacting with few viruses (10f 9 , 27b3) are probably directed to epitopes that are highly variable due to immunological pressure by neutralizing antibodies. These strain-specific or discriminatory mAbs have been widely used and have proven to be extremely useful in several areas of research $(7,16,22,27,30-32)$.

Several groups have attempted to subdivide BVDV strains into distinct antigenic groups either by monoclonal antibody binding or by neutralization assays $(7,27,30$, 32,33 ). Thus far, none of the hiterto proposed mAb-based group classifications seems to have universal applicability $(7,30)$. Although mAbs may allow distinction among viruses by minor differences, polyclonal antisera are better suited to divide BVDV isolates into groups. In this study, allocation of isolates to antigenic groups was not attempted due to the small number of 
viruses examined. Nonetheless, it was possible to identify discrete clusters of viruses whose antigenic profile may provide the basis for a tentative group allocation. Patterns of reactivity revealed a group of viruses including UFSM-1, 153.1, 153.15, 153.19 and 126.14 which are very distinct from the reference strains. The main variability of these viruses is related to the lack of recognition by most E2/gp53 mAbs. These isolates also showed an almost identical mAb reactivity profile within the group. The reactivity profile of the other isolates was highly diverse, not allowing an easy identification of distinct groups of antigenically related viruses.

Neutralization studies using monospecific bovine or sheep antisera have detected up to 100-fold differences in cross-neutralization titers among BVDV field isolates $(15,30,33)$. In the present study, a few 68 and 128-fold differences were observed for some pairs of viruses, whereas differences of 16- and 32-fold were common throughout the comparisons. Interestingly, many of the 16-, 32- and 64-fold differences in crossneutralization titers involved the Singer strain (virus/serum) against the isolates (or serum) mentioned above. The low cross-reactivity observed among many of the pairs examined reflects the marked antigenic diversity detected by mAb analysis, suggesting that the immune response to a given virus may not be protective against an antigenically distinct isolate.

Recently, genotypically different BVDV strains have been associated with high mortality in calves in the US and Canada $(8,28,29)$. These viruses, tentatively termed BVDV type II $(28,29)$, display a low serologic cross-reactivity with the classical BVDV strains, now termed type I BVDV (29). In our study, VN titers involving isolate 63 showed significant variations all across the comparisons, with its antiserum showing a poor neutralizing activity against most of the viruses examined. The calculation of antigenic similarity reinforced the marked antigenic diversity and indicated the existence of rather distinct viruses among the Brazilian isolates. $\mathrm{R}$ values that antigenically distinguish strains $(<25)$ were observed for several pairs of viruses, most consistently for isolates 63 (all its $\mathrm{R}$ values were below 25), UFSM-1 and 3, 126.14 and 123.4. Furthermore, $\mathrm{R}$ values that suggest allocation of viruses to distinct serologic groups were observed for isolate 63 (five $\mathrm{R}$ values below 5) but also for UFSM-1, UFSM-3 and 123.4. Noteworthy are the low $\mathrm{R}$ values obtained for isolate 63 when compared to the Singer, NADL and Oregon/C24v strains. These laboratory reference strains have been unequivocally classified as BVDV type I $(28,29)$ and have shown a low serological cross-reactivity with North-American type II BVD viruses (29). The quite distinct antigenic profile displayed by isolate 63 and its distant antigenic relatedness to reference type I BVDV strongly suggest that this virus belongs to a distinct serologic group within BVDV. Genomic sequencing and analysis of these isolates are currently underway and will better define a possible group allocation for Brazilian BVDV isolates.

The biological significance of the antigenic diversity of BVDV remains poorly understood although its possible implications seem rather more clear. This antigenic variability may be positively exploited in epidemiologic studies on the patterns of virus spread, to discriminate between viruses and to determine the origin of isolates involved in field outbreaks $(7,16,20,24)$. Likewise, the variability of surface glycoproteins has been used to study the epitopes involved in virus neutralization $(22,31)$ and may be useful for studying virus-host cell interactions and identifying virulence and tissuecell tropism determinants $(31,34,35)$. On the negative side, the antigenic variability may affect the specificity and sensitivity of immunological tests used in laboratory diagnosis $(7,24)$. Furthermore, the existence of field 
isolates that are poorly neutralized by antisera to reference vaccine strains raises the question about the degree of protection conferred by such vaccines. Since most BVDV vaccines available in Brazil are based on a single US or European strain, it is pertinent to question whether these vaccines will protect against native viruses.

The antigenic characterization of an additional number of isolates is needed to provide a more comprehensive understanding of the antigenic characteristics of BVDV present in Brazilian cattle. Nevertheless, the antigenic variability demonstrated in this study indicates that a reevaluation of diagnostic procedures, vaccine manufacturing and immunization strategies may be necessary to efficiently diagnose and control
BVDV infection in Brazil.

\section{Acknowledgments}

We thank Dr. Ruben Donis (University of Nebraska at Lincoln, Lincoln, NE, USA) for providing the $\mathrm{mAbs}$ and the reference BVDV strains. Isolates IBSP-1, 2, 4 and 5 were isolated and provided by Dr. E. Maristela Pituco (Instituto Biológico de São Paulo, SP) and isolates LV96 and EVI-006 were provided by Dr. Valéria Moojen (Faculdade de Veterinária, Universidade Federal do Rio Grande do Sul, Porto Alegre, RS) and Dr. Paulo M. Roehe (Centro de Pesquisas Veterinárias Desidério Finamor, Eldorado do Sul, RS), respectively.

\section{References}

1. Horzinek M (1991). Pestiviruses - taxonomic perspectives. Archives of Virology, Suppl 3: 1-5.

2. Bolin SR (1990). The current understanding about the pathogenesis and clinical forms of BVD. Veterinary Medicine, 85: 1123-1132.

3. Francki RIB, Fauquet $\mathrm{CM}$, Knudson $\mathrm{DL} \&$ Brown F (1991). Classification and nomenclature of viruses. Fifth Report of the International Committee on the Taxonomy of Viruses. Archives of Virology, Suppl 2: 223-233

4. Collett MS, Moenning V \& Horzinek MC (1989). Recent advances in pestivirus research. J ournal of General Virology, 70: 253-266.

5. Collett MS, Larson RE \& Gold C (1988). Molecular cloning and nucleotide sequence of the pestivirus bovine viral diarrhea virus. Virology, 70: 253-266.

6. Nettleton PF (1990). Pestivirus infections in other ruminants than cattle. Revue Scientifique et Technique, Office International des Epizoties, 9: 131-145.

7. Edwards S \& Paton D (1995). Antigenic differences among pestiviruses. Veterinary Clinics of North America, 11: 563578.

8. Corapi WV, French TW \& Dubovi EJ (1989). Severe thrombocytopenia in young calves experimentally infected with noncytopathic bovine viral diarrhea virus. J ournal of Virology, 62: 2823-2827.

9. Brownlie J (1991). The pathways for bovine viral diarrhea virus biotypes in the pathogenesis of disease. Archives of Virology, Suppl 3: 79-86.

10. Baker J C (1995). The clinical manifestations of bovine viral diarrhea infections. Veterinary Clinics of North America, 11: 427-444.

11. Meyers G, Tautz N \& Dubovi EJ (1991). Viral cytopathogenicity correlated with integration of ubiquitin-coding sequences. Virology, 180: 602-610.

12. Donis R (1995). Molecular biology of bovine viral diarrhea virus and its interactions with the host. Veterinary Clinics of North America, 11: 393-421.

13. Fernelius $A L$, Lambert $G \&$ Boot $G D$ (1971). Bovine viral diarrhea virus-host cell interactions: serotypes and their relationship to biotypes by cross-neutralization. American J ournal of Veterinary Research, 32: 229-236.

14. Hafez SM \& Liess B (1972). Studies on bovine viral diarrhea-mucosal disease virus. I. Cultural behaviour and antigenic relationship of some strains. Acta Virologica, 16: 388-398.

15. Howard CJ, Brownlie J \& Clarke MC (1987). Comparison by the neutralization assay of pairs of non-cytopathogenic and cytopathogenic strains of bovine virus diarrhoea virus isolated from cases of mucosal disease. Veterinary Microbiology, 13: 361-369.

16. Dubovi EJ (1992). Genetic diversity and BVD virus. Comparative Immunology and Microbiology of Infectious Diseases, 15: 155-162.

17. Correa WM, Netto ZC \& Barros HM (1968). Nota clínico-patológica de uma enfermidade das mucosas em São Paulo. Arquivos do Instituto Biológico de São Paulo, 35: 141-151.

18. Correa WM, Gottschalk AF \& Correa C (1972). Observações na diarréia a vírus dos bovinos no Estado de São Paulo. Arquivos do Instituto Biológico de São Paulo, 38: 145-147.

19. Soares LA \& Carvalho Pereira OA (1974). Neutralizing antibodies against bovine viral diarrhea virus-mucosal disease virus in cattle sera from São Paulo, Brazil. Revista de Microbiologia, 5: 1-5.

20. Roehe PM, Oliveira EAS \& Oliveira LG (1995). Characterization of field and cell culture isolates of bovine viral diarrhea virus (BVDV) with monoclonal antibodies. Anais da 5a Virológica, Ribeirão Preto, SP, 26-29 Novembro 1995, B-6.

21. Oliveira LG, Oliveira EAS, Silva LHT, Vieira LA, Hoffmann VL, Fernandes GV, Silva TC, Caldas APF \& Roehe PM (1996). 
Presença de pestivírus e anticorpos contra pestivírus em soros e cultivos celulares. Arquivo Brasileiro de Medicina Veterinária e Zootecnia, 48: 513-521.

22. Corapi WV, Donis RO \& Dubovi EJ (1990). Characterization of a panel of monoclonal antibodies and their use in the study of the antigenic diversity of bovine viral diarrhea virus. American J ournal of Veterinary Research, 51: 1388-1394.

23. Archetti I \& Horsfall FL (1950). Persistent antigenic variation of influenza $A$ viruses after incomplete neutralization in ovo with heterologous immune serum. J ournal of Experimental Medicine, 92: 441-462.

24. Carman S, Von Dreumel T, Hazlett M, Alves D, Dubovi EJ , Ridpath J , Bolin SR \& Tremblay R (1996). A diagnostic laboratory in the middle of an acute outbreak of BVDV. Proceedings of the International Symposium on BVDV: A 50 year review. Ithaca, NY, J une 22-24, 1996, 79-85.

25. Baker J A, York CJ , Gillespie J H \& M itchell GB (1954). Virus diarrhea in cattle. American J ournal of Veterinary Research, 15: 525-531.
26. Taylor DON, Gustaffson DP \& Claflin RM (1963). Properties of some viruses of the mucosal disease-virus diarrhea complex. American J ournal of Veterinary Research, 24: 143-149.

27. Edwards $S$, Moenning $V \& \&$ Wensvoort $G$ (1991). The development of an international reference panel of monoclonal antibodies for the differentiation of hog cholera virus from other pestiviruses. Veterinary Microbiology, 29: 101-108.

28. Ridpath J, Bolin S \& Dubovi E (1994). Segregation of bovine viral diarrhea virus into genotypes. Virology, 205: 66-74.

29. Pellerin C, van den Hurk J \& Lecomte J (1994). Identification of a new group of bovine viral diarrhea virus strains associated with severe outbreaks and high mortalities. Virology, 203: 260-267.

30. Paton D, Sands J J, Lowings J P, Smith J E, Ibata G \& Edwards S (1995). A proposed division of the pestivirus genus using monoclonal antibodies, supported by cross-neutralization assays and genetic sequencing. Veterinary Research, 26: 92109.
31. Weiland E, Stark R, Haas B, Rumenapf $T$, Meyers G \& Thiel HJ (1990). Pestivirus glycoprotein which induces neutralizing antibodies forms part of a disulfide-linked heterodimer. J ournal of Virology, 64: 3563-3569.

32. Bolin S, Moennig V, Gourley NEK \& Ridpath J (1988). Monoclonal antibodies with neutralizing activity segregate isolates of bovine viral diarrhea virus into groups. Archives of Virology, 99: 117-118.

33. Wensvoort G, Terpstra C \& de Kluyver EP (1989). Characterization of porcine and some ruminant pestiviruses by cross-neutralization. Veterinary Microbiology, 20: 291-306.

34. Flores EF \& Donis R (1995). Isolation and characterization of a mutant MDBK cell line resistant to infection with bovine viral diarrhea virus due to a block in viral entry. Virology, 208: 565-575.

35. Flores EF, Kreutz LC \& Donis R (1996). Ruminant and swine pestiviruses require a common cell surface factor to enter bovine cells. J ournal of General Virology, 77: 1295-1303. 